\title{
Managing the Tradition and Innovation Paradox in Family Firms: A Family Imprinting Perspective
}

\author{
Irmak Erdogan \\ Altinbas University \\ School of Business Administration \\ Büyükdere Caddesi, 147 \\ 34394 Esentepe, Istanbul, Turkey \\ irmak.erdogan@altinbas.edu.tr
}

\begin{abstract}
Emanuela Rondi
(corresponding author)

Free University of Bozen-Bolzano

Faculty of Economics and Management

Centre for Family Business Management

Universitätsplatz 1 - Piazza Università, 1

39100 Bozen-Bolzano, Italy

emanuela.rondi@unibz.it
\end{abstract}

\author{
Alfredo De Massis \\ Free University of Bozen-Bolzano and Lancaster University \\ Faculty of Economics and Management \\ Centre for Family Business Management \\ Universitätsplatz 1 - Piazza Università, 1 \\ 39100 Bozen-Bolzano, Italy \\ alfredo.demassis@unibz.it \\ and \\ Lancaster University (UK)
}

\section{Accepted for publication in Entrepreneurship Theory \& Practice}

Please cite as:

Erdogan I., Rondi E., De Massis A. (2019). Managing the tradition and innovation paradox in family firms: A family imprinting perspective. Entrepreneurship Theory \& Practice, In press. 


\section{Managing the Tradition and Innovation Paradox in Family Firms: A Family Imprinting Perspective}

Long-established family firms are endowed with a bundle of beliefs and practices that constitute their tradition. However, to remain competitive, they need to renew and update their products and production processes. Such forces pulling toward the past and the future, antithetically calling for continuity and change, seem paradoxical. In an abductive analysis of eight longestablished family firms in Turkey, we identify four equifinal strategies to manage this paradox. Adopting a family imprinting perspective, we theorize how the long-lasting legacy of previous family generations shapes different approaches to innovation and tradition depending on the content imprinted on the current family generation. Contributing to family business, imprinting, and innovation research, we identify temporal symbiosis as a firm's simultaneous adoption of retrospective and prospective approaches to using its resources to concurrently perpetuate tradition and achieve innovation, highlighting its crucial role as a shield of the past and engine for the future.

Keywords: Tradition, Innovation, Family Firms, Paradox, Imprinting, Abductive research.

\section{Introduction}

"If modern middle-class people have more knowledge and choices then their grandparents, what is the point of deferring to the advice of less enlightened relatives, living or dead? " (Soares, 1997, p. 9)

Tradition - "consciously transmitted beliefs and practices expressing identification with a shared past" (Dacin, Dacin, \& Kent, 2019, p. 356) - is preserved through the complex interpretations of the custodians who shield it (Hibbert \& Huxham, 2010). In family firms, tradition is handed down from generation to generation, for example, through storytelling (Kammerlander, Dessi, Bird, Floris, \& Murru, 2015), physical objects embodying values, and rituals (Fiese et al., 2002). It implies the strong recognition of ancestors who imprinted the "organizational tradition" at the formation stage (Stinchcombe, 1965, p.160) that survives and persists over time (Marquis \& Tilcsik, 2013), within and among generations (Hammond, Pearson, \& Holt, 2016). The invariant core of tradition shapes the family firm's identity and its modus operandi, paving the way for continuity, and spurring next generations to accept and enact it (Dacin \& Dacin, 2008). Thus, shared beliefs, rituals, practices, and legacy help family firms persist over time, albeit potentially posing a substantial constraint to change (Lumpkin, Martin, \& Vaughn, 2008), particularly for those with high attachment to their tradition (Rondi, De 
Massis, \& Kotlar, 2018).

Nevertheless, family firms need to change and innovate to remain competitive. Innovation requires breaking with continuity to develop new competences and skills (Adner \& Snow, 2010). Family business prosperity across generations depends on innovation (Jaskiewicz, Combs, \& Rau, 2015) to achieve desirable future outcomes and long-term goals (Diaz-Moriana, Clinton, Kammerlander, Lumpkin, \& Craig, 2018). Although family involvement in the business is argued to influence innovation (e.g., Calabrò et al., 2018; De Massis, Frattini, \& Lichtenthaler, 2013), forging a long-run mindset embracing the past, present, and future (De Massis, Audretsch, Uhlaner, \& Kammerlander, 2018), the question of how family firms manage innovation activities remains largely unanswered due to the scarcity of in-depth research analyzing the dynamics underlying their innovation strategies (e.g., Dieleman, 2018).

While tradition is about the past, commitment, and stability (Linnekin, 1983), innovation is all about change (Damanpour, 1991). These two elements are crucial for family firms, as solely sticking to tradition would result in losing competitiveness, and exclusively pursuing innovation would erode their core and distinctive legacy. Tradition and innovation are typically seen as two antithetical concepts (Shoham, 2011), and their coexistence would seem paradoxical. Therefore, family firm leaders need to learn how to manage such paradoxical tension to avoid decision making paralysis (Ingram, Lewis, Barton, \& Gartner, 2016). Recently, De Massis, Kotlar, Frattini, Messeni Petruzzelli, and Wright (2016) investigated how family firms can create and nurture competitive advantage by leveraging their tradition, conceptualizing a new product innovation strategy labeled "innovation through tradition". This is a first attempt suggesting that tradition might play an important role in family firm innovation, encouraging empirical research into how tradition and innovation can interact and coexist in family firms. Thus, tradition would seem an important lens through which to examine the question of "how" family firm innovation occurs.

To address this point, we focus on the under-researched area of family business innovation 
activities (Röd, 2016; Dieleman, 2018), recognizing the complexity of the phenomenon, and adopting an alternative approach to answer our research question: How do family firms manage the paradox between tradition and innovation? Exploring eight longstanding Turkish family firms in the craft industry through interviews, observations, and archival data from 1933 to 2018, we identify different equifinal strategies through which they manage the tradition and innovation paradox. By abductively iterating from our findings to theory, we shed light on previous family generations' imprinting on current behavior. We use imprinting theory to explore the role of imprinting content (product signs, family values and beliefs) in shaping the family firm's approach to innovation and tradition, ultimately driving its strategies.

Given the prominence of tradition in family firms (Lumpkin et al., 2008), and its currently overlooked significance in innovation research, our study integrates empirical evidence with extant theory to offer three main contributions. First, we contribute to the family firm innovation literature by enhancing our understanding of what makes family firm innovation distinctive. Our study provides empirical qualitative evidence for the argument that tradition is a fundamental constituent of the particular nature of family firm innovation. Therefore, for long-established family firms with a strong heritage, tradition provides a distinct and unique bundle of resources that are potential sources of competitive advantage, yet also a boundary to their discretion to change (Dacin et al., 2019). Counterintuitively, we also unveil that family firms can leverage innovation to preserve and pursue their "tradition through innovation". Second, we contribute to the imprinting literature by offering insights on the enduring impact of the former family generation on current family members involved in the business. We analyze different types of content that can be imprinted as well as their influence on the strategies implemented by the current generation leading the business (Marquis \& Tilcsik, 2013). Third, we challenge the conceptualization of tradition and innovation as paradoxical forces (e.g., Gusfield, 1967; Schuman, Stutz, \& Ward, 2010). Through our empirical analysis, we show that the imprinting of tradition does not necessarily hamper innovation, but can boost the development of new 
products or processes. Our findings indicate that family firms can innovate by simultaneously perpetuating their tradition, and do so in different ways. By shifting the focus from the binary opposition of tradition and innovation to the process through which each can contribute to the other, we introduce the new temporal symbiosis construct, offering insights on how the paradox between tradition and innovation can be managed.

\section{Tradition and Innovation in Family Firm Research}

\section{Tradition in Family Firms}

Recent attention to the role of legacy and history in organizational processes (Schultz \& Hernes, 2013) highlights the "power of the past" when actors engage in manufacturing and reproducing tradition and heritage passed down through successive generations (Weber \& Dacin, 2011). The attributes that an organization acquires in sensitive periods (limited time intervals with high susceptibility to external influences (Marquis \& Tilcsik, 2013), such as the founding stage) imprint the organization with tradition that can survive in future periods (Stinchombe, 1965). Tradition can involve tangible resources, such as objects, books, and paintings, and intangible resources, such as stories, histories (Kammerlander et al., 2015), events, rites, (Harrison, 2013), stocks of knowledge and competencies (Messeni Petruzzelli \& Albino, 2012), with a sequential social structure that gains consensus over time (Shils, 1971). Long-established organizations may be endowed with tradition, particularly in the craft industry where core activities are grounded in the mastery and savoir-faire adopted to develop the uniqueness that forges organizational identity (Dion \& Arnould, 2011).

Depending on traditionalizing mechanisms (Simsek, Fox, \& Heavey, 2015), imprinted tradition can continue or decay over time (Marquis \& Tilcsik, 2013). To be continued, tradition requires protection from threats to objects, places, and practices (Dacin \& Dacin, 2008), a role played by custodians - "individuals or groups who are vested in the continuity of traditions and who carry, invent, guide, adapt and protect them" (Dacin et al., 2019, p. 351). Toolkits for manufacturing and reproducing tradition are handed across generations, providing inputs for 
market creation, cultural integrity, and identity formation (Weber \& Dacin, 2011). The adaptation or change in institutionalized practices may result in either erosion or enhancement of tradition over time (Soares, 1997). One reason why tradition disappears is deinstitutionalization, where political, functional, or social pressures spur either the gradual dissipation or rejection of practices, leading to its erosion (Oliver, 1992). Nevertheless, even after a tradition has been eroded, what appear to be an organization's bygone characteristics can re-emerge through remnants of the original tradition - stories, physical objects, rituals, temporal connections, or linkages to place, sentiments, and memories - useful to re-invent or construct a new tradition, years or even decades later (Dacin \& Dacin, 2008).

Although tradition is generally important to long-established firms, allowing to perpetuate identity over time through organizational beliefs and practices (Dacin, Munir, \& Tracey, 2010), it is of paramount importance to family firms (Hammond et al., 2016), where it also serves to perpetuate the family's beliefs and practices. The family component adds a whole new dimension to the discussion, as routines and rituals based on shared history and practices serve to connect family members within and among generations, creating unity (Dacin et al., 2019). Indeed, filiation - belonging to a family, legitimacy of a belief and/or practice handed down or inherited over time - is an inner characteristic of tradition (Shils, 1971). Thus, family firm members perceive tradition as a bequest from past generations to be shielded and bequeathed to subsequent generations (e.g., Andersson, Carlsen, \& Getz, 2002; Jaskiewicz et al., 2015), but this can hamper future change. Consequently, we expect tradition to interfere with family firm innovation activities (e.g., Voyatzaki, 2013).

\section{Innovation in Family Firms}

Scholars studying family firms find theoretical and empirical support for the argument that family involvement affects innovation inputs, outputs, and activities (De Massis, Frattini, Pizzurno, \& Cassia, 2015). Family firms are often found more able to innovate due to their higher discretion to allocate resources, yet less willing to do so (Chrisman, Chua, De Massis, Frattini, 
\& Wright, 2015). Although research on family business innovation is gaining momentum (Calabrò et al., 2018), the activities enacted by family firms to innovate have received less attention compared to innovation inputs and outputs (Röd, 2016; Dieleman, 2018). Moreover, the few studies tackling innovation activities (e.g., Classen, Van Gils, Bammens, \& Carree, 2012; Mazzelli et al., 2018; Chirico et al., 2018) compare family vs non-family firms rather than exploring the underlying mechanisms of how family businesses innovate. Thus, how family firms manage innovation remains little understood, and given the importance of tradition in the family firm context, recent studies have called for research on the influence of past generations on future generations' innovation behavior (e.g., Diaz-Moriana, et al., 2018).

\section{The Tradition and Innovation Paradox in Family Firms}

It is widely recognized that the coexistence of family values and goals alongside firm aspirations (e.g., Chrisman, Chua, Pearson, \& Barnett, 2012; Zellweger, Chrisman, Chua, \& Steier, 2018) can lead to various tensions in family firms (Schuman et al., 2010). As a result, family firms embrace contrasting tendencies, such as stability vs proactiveness, or interdependency vs autonomy (Lumpkin et al., 2008; Rauch, Wiklund, Lumpkin, \& Frese, 2009). Given that tensions are considered underlying sources of paradox (Lewis, 2000; Smith \& Lewis, $2011)^{1}$, it is unsurprising that tensions in different areas, such as goals, values, and practices, give rise to many paradoxes in family firms. Nevertheless, this makes the study of family firms particularly valuable, posing both opportunities and challenges (Schuman et al., 2010). Differently from dilemmas that require a trade-off, the contradiction that characterizes a paradox is supposedly unresolvable, and emphasis on only one side of the tension would lead to issues such as anxiety and decision making paralysis (Ingram et al., 2016). Managing a paradox and escaping paralysis requires exploring rather than suppressing tensions (Smith \& Berg, 1987).

\footnotetext{
${ }^{1}$ We adhere to Smith and Lewis' (2011, p. 382) definition of paradox as "contradictory yet interrelated elements that exist simultaneously and persist over time". This definition highlights two components of paradox: (i) underlying tensions - elements that seem logical individually but inconsistent and even absurd when juxtaposed, and (ii) responses that embrace tensions simultaneously.
} 
Among the tensions characterizing family firms, the tension between clinging to tradition and pursuing innovation is particularly manifest, leading to an important tradition and innovation paradox $^{2}$. In long-established family firms endowed with tradition bequests and doomed to renewal, an either/or approach to tradition and innovation is detrimental. By sticking to their tradition, family firms would lose competitiveness, while by merely innovating, they would discard the essential beliefs and practices that shape their identity over time. Hence, family firm leaders need to explore the tension between tradition and innovation (Voyatzaki, 2013), and learn how to manage the paradox characterizing family firm behavior (Moores \& Barrett, 2002; Schuman et al., 2010). The role of tradition in family firm innovation has long been overlooked and only recently started receiving attention (e.g., De Massis et al., 2016; Kammerlander et al., 2015, Rondi et al., 2018), leaving many important questions unaddressed (Diaz-Moriana et al., 2018). Moreover, tradition scholars call for further exploration of the temporal nature of tradition, including its impact on activities in the past, present, and future (Dacin et al., 2019). Therefore, exploring the interaction between tradition and innovation in family firms is a promising avenue for developing insightful research and empirical contributions.

\section{Research Design}

\section{Methodology}

To address our research question, we designed an empirical qualitative study based on multiple cases (Yin, 2003; Eisenhardt, 1989). A qualitative approach is particularly appropriate given the focus on the "how" question (Yin, 2003). Case studies are frequently used in family firm research (e.g., Steier \& Greenwood, 2000; Miller, Steier, \& Le Breton-Miller, 2003), recognized as "a valuable method for family business scholars to describe complex phenomena, develop new theory or refine and extend existing theories" (De Massis \& Kotlar, 2014, p. 16).

\footnotetext{
${ }^{2}$ Worth noting is that the tension between tradition and innovation has its roots in the sociological concept of 'modernization' (Soares, 1997) based on a conceptual opposition of tradition and modernity (Shoham, 2011). In a modern society, tradition would perish, and modernity would triumph, since being traditional would make one antiquarian, trapped in the reiteration of past against progress (Weber, 1982), while doing something new requires creative and deliberate thought and the demise of tradition (Soares, 1997). Tradition, seeking continuity, is thus in antithesis with innovation, calling for change.
} 
Moreover, recent research has emphasized the potential of qualitative methods in addressing issues of contradiction and paradox in family firms (Fletcher, De Massis, \& Nordqvist, 2016). Our multiple-case study enables unveiling the underlying processes and practices that family firms enact in managing the tradition and innovation paradox.

\section{Research Context}

Our research is grounded in insights from long-established family craft firms in Turkey. Usually conceptualized as a bridge between the East and the West, Turkey has undergone many reforms, revolutions, and societal changes throughout its history (Shaw \& Shaw, 1977), while preserving its collectivistic tendencies (Kağıtçıbaşı, 1996), emphasizing interdependence, protection, and loyalty (Hofstede, 1980). The Turkish family is typically described as an emotionally interdependent unit with individual and group loyalties (Kağıtçıbaşı, 1996). This suggests that preservation of tradition is especially important in the family unit, thus the relevance of research on tradition in the context of Turkish family firms.

In line with the family's central role in society, the extent of family control in enterprises is reported to be considerably high in Turkey, regardless of the size and scope of business operations (Bugra, 1994). According to the European Commission (2008), family firms represent $90 \%$ of all enterprises in Turkey, estimated at around $94 \%$ when considering only small and medium sized enterprises (Ankara Chamber of Commerce, 2005). In terms of innovation, Turkey's strength lies in its innovation efficiency (Global Innovation Index, 2016). Given its disadvantages in terms of elements of the national economy that enable innovative activities (e.g., political environment, government expenditure), Turkey has relatively high innovation outputs (Global Innovation Index, 2016).

Turkey went through a major transformation following the collapse of the Ottoman Empire and the foundation of the Turkish Republic in 1923, and the stimulation of Western-style economic development and modernization through several reforms in the 1920s and 1930s (Renda \& Kortepeter, 1986). This required a radical break with the past and the creation of an 
entity completely independent of the empire (Atabaki \& Brockett, 2009). Often referred to as an elitist project, this modernization has been criticized for its manufactured character imposing a secularist vision on a traditional society (Kadığlu, 1996; Rasaba \& Larabee, 2008). Republicans, on the other hand, rather than contrasting modernization with tradition, saw it in antithesis to the conservative tendencies to reinstate the Ottoman sultanate and Sunni caliphate (Erdemir, 2005). As a result, Turkish nationalism has imposed the challenging task of achieving a balance between westernization and Turkish culture (Kadığlu, 1996). Thus, we believe the long-established tensions and conflicts between continuity and change (Kerslake, Öktem, \& Robins, 2010), and the high levels of efficiency in innovative activities make Turkey an ideal context to study the family business paradox between tradition and innovation.

\section{Case Selection}

Following Eisenhardt's (1989) recommendations of 4 to 10 extreme cases in which the phenomenon of interest is "transparently observable" (p. 537), we selected 8 long-established Turkish family firms in the craft industry. In addition, we identified 3 theoretical sampling criteria that allowed us to reach the "richest and most relevant data" (Draucker, Martsolf, Ross, \& Rusk, 2007, p. 1138). Firm age constituted the first: long-established firms are potentially characterized by strong tradition, yet have managed to change and survive over multiple generations. Moreover, the survival rates of Turkish firms are below world average, and longestablished firms are rarely found (Ankara Chamber of Commerce, 2005). Given that the Turkish Republic was established in 1923 and the lack of univocal information on firms founded before 
this date, we integrated 4 different databases $\left(\mathrm{AGMER}^{3}, \mathrm{ITO}^{4}, \mathrm{PwC}^{5}\right.$, and $\left.\mathrm{YMD}^{6}\right)$, identifying Turkish firms founded no later than the 30 s to capture those that have undergone the transition of westernization vs conservatism in Turkey. The second sampling criterion required that firms operate in the craft industry, where high value is placed on tradition, creating conflict for craftsmen who simultaneously need to conform to societal demands and industrial capitalism (Ranson, 1989). Recently, the craft industry has faced the transition from traditional craft skills to machine skills (Vyas, 1991; Woolley, 2011), which makes the tradition-innovation paradox particularly observable in this context. Third, to capture the family firm element, we refined our sample in relation to high levels of family involvement and essence (Chrisman, Sharma, Steier, \& Chua, 2013). Thus, the final criterion required that the family owns all the shares, is actively involved in managing the business, and has the intention to hand it over to the next generation, a common proxy of family essence (Chrisman et al., 2012).

We gathered the most valid and up-to-date information from company websites to ensure that the theoretical sampling criteria were satisfied. After identifying the family firms to potentially include in our study, we contacted their representatives and asked if they would be willing to be interviewed and provide access to other sources of information. Our final sample consists of 8 long-established family firms operating in the craft industry (i.e., watch sales and service, diary and notebook manufacturing, wine and beverage production, food production and restaurant) that have the "rare or extreme" qualities appropriate to our investigation (Eisenhardt \& Graebner,

\footnotetext{
${ }^{3}$ AGMER (Aile İşletmeleri ve Girișimcilik Araştırma ve Uygulama Merkezi) is Turkey's first research center founded in 2004 specifically to study family business issues at the university level and remedy the dearth of insights on the grassroots of the Turkish economy. The AGMER database includes long-lived family firms in Turkey (further information available at: https://www.iku.edu.tr/6/426/kidemli-aile-isletmeleri.html).

${ }^{4}$ ITO (İstanbul Ticaret Odasi) is the Istanbul Chamber of Commerce. Founded in 1882, ITO is an institution that organizes and records the commercial transactions of individuals and commercial institutions in Istanbul. The ITO (2013) database is based on an ITO book on Turkey's and Istanbul's centennial firms (both family and nonfamily).

${ }^{5} \mathrm{PwC}$ (PricewaterhouseCoopers) is a global advisory company that since 1981 provides industry-focused assurance, tax, and advisory services to the Turkish business world, with five offices located in Istanbul (two), Ankara, Bursa, and İzmir, and a professional staff of 1700 people. The PwC database is based on a PwC survey (PwC Family Business Survey 2010/11) reported in a newspaper article listing the 20 oldest firms in Turkey (Radikal, 2011).

${ }^{6}$ YMD (Yüzylllık Markalar Derneği) is the association of Turkish century-old brands aiming to lead the way in creating, preserving, and advancing brands by sharing century-old common cultural values, know-how, and experience with society. It includes Turkey's treasured brands that have served as a commercial, economic, and cultural cornerstone from the Ottoman Empire era through the foundation of the Republic to the present day (further information available at http://www.yuzyillikmarkalar.org/EN/Hakkimizda.aspx).
} 
2007, p. 27). Table 1 provides detailed information on our sample and the evidence collected.

\section{Data Collection}

--- Insert Table 1 about here ---

Our study employs a combination of primary (interviews and observations) and secondary (archives) data sources. We developed an interview protocol comprised of a set of open questions starting with demographic information on the individual and the business, changes in products and production methods over generations, family tradition pertaining to products and production methods, the message they convey to family members, family values and beliefs, and their motivation for continuity and change over generations. We iteratively revised the interview protocol during data collection. From May to December 2015, the first author conducted 16 semi-structured in-depth interviews with the 8 family firms at the headquarters, lasting between 40 minutes and 4 hours. A follow-up interview with a family member was conducted in one case in 2018, yielding a total 17 interviews (14 with family members, 3 with nonfamily managers). All interviews were in Turkish, recorded and transcribed verbatim by the first author immediately after the interview.

We then triangulated the interviews with observations. The first author conducted field visits, took photographs (of products, objects, documents, pictures, menus, machines, etc.), engaged in informal conversations with family and nonfamily employees, and observed the interactions of family members with each other, with nonfamily employees and customers. In some cases, she visited the production sites and collected or consumed products.

Since the sample consists of some of the oldest well-known businesses in Turkey, a very large amount of secondary data was also available, which allowed us to effectively triangulate a wide range of sources. These secondary data were gathered from company webpages, newspaper, magazine, and TV interviews, documentaries, videos, TV commercials, press releases, books and chapters about the family firms. In some cases, the families also gave access to private company or personal documents related to their history or writings. 


\section{Data Analysis}

We analyzed the data using an abductive approach (Locke, Golden-Biddle, \& Feldman, 2008). In the first step, the first two authors reviewed the primary and secondary data independently, highlighting the material reflecting tradition and innovation in family firms. Then, the two authors analyzed all the material and created first-order codes reflecting the practices the firms implemented. In this step, the within-case analysis was followed by a crosscase analysis to compare the findings of each case and revise the emerging themes accordingly, moving from data to theory (Eisenhardt, 1989). In the second step, the authors gradually collapsed the first-order codes into more abstract second-order themes and aggregate dimensions. At this point, the third author read all the material and went back to the recorded data to see if the codes fitted the emerging abstractions. When this was not the case, the three authors met, reviewed inconsistencies, and revised the categories accordingly. Figure 1 shows our final data structure. In the third step, the three authors integrated the emergent findings with elements from imprinting theory to develop a model explaining the adoption of different strategies to manage the tradition and innovation paradox.

\section{--- Insert Figure 1 here ---}

\section{Findings}

Our analysis revealed that the family firms in our sample varied in two approaches to tradition and two approaches to innovation. The preservation approach to tradition denotes firms in which the family shows continuous commitment to the founder's values, beliefs, and craftsmanship. Conversely, the revival approach to tradition characterizes firms where some elements of the familial tradition have faded over time and they regret such loss. Hence, these firms search and recover past elements to revive tradition. Moreover, we observed that the firms differed in their approach to innovation. While some adopted a segregation approach, characterized by iconic products distinguished from new products and processes, others adopted an integration approach by protecting the essence and reinterpreting traditional products and production through 
innovation. Based on our evidence, the 8 family firms can be categorized into 4 strategies according to their approach to managing the tradition and innovation paradox ${ }^{7}$, as depicted in the matrix in Figure 2. Table 2 provides exemplary quotes for these categories that we explore next.

\section{Approach to Tradition}

--- Insert Figure 2 and Table 2 here ---

Preservation. Some family firms in our sample are committed to the values, beliefs, and customs imprinted by their iconic founders. One example is the Winery Case, founded in 1926 and currently managed by the 2nd and 3rd generations. Until the foundation of the Turkish Republic in 1923, wine consumption was prohibited for Muslims. In 1923, the grandfather moved to Germany and studied Oenology. Upon his return in 1926, he opened the first wine production facility in Turkey, becoming the first Muslim to engage in wine production. His heroic presence remains very strong within the family.

"An extraordinary vision [...] My grandfather passed away when I was 6. What courage he had when he founded the firm" (Manager, 3rd generation; interview)

The family attaches strong meanings and values to their craftsmanship that still influence their current positioning.

"Winemaking is a family tradition. I continue this tradition” (Manager, 3rd generation; newspaper interview)

"We would never change our principles and ethics. We have always protected our standing” (Manager, 3rd generation; interview)

Another example is the Quartz Case, a family firm specialized in selling and repairing mechanical watches since 1889 , currently run by the 3rd and 4th generations. Similarly to the Winery Case, the founder was a pioneer in his sector.

"There were not so many Turkish Muslim traders at that time, especially not in the watch sector. He was among the first" (GM, 3rd generation, interview)

The founder's story and the value he assigned to family craftsmanship were passed down to the next generations. During the technological transition toward quartz watches, all competitors

\footnotetext{
${ }^{7}$ A strategy is defined as "the fundamental characteristics of the match that an organization achieves among its skills and resources and the opportunities and threats in its external environment that enables it to achieve its goals and objectives" (Chrisman, Hofer, \& Boulton, 1988, p. 414).
} 
started abandoning mechanical watches, but the family decided to keep them in their current offer to protect the 80-year old family tradition, despite the financial implications.

"When you say 126 years, people stop for a second. Why not make it 200 years? Continuing the family tradition and keeping my grandfather's name alive is what excites me most" (Sales Manager, $4^{\text {th }}$ generation; interview)

"There is such a heritage here, such an accumulated experience. More people should know about this" (Corporate Communications Manager, $4^{\text {th }}$ generation; interview)

In the Bake Case, a 5th generation bakery founded in 1836, family craftsmanship was part of the family tradition imprinted even before founding the firm. The family has been involved in the craft since before 1836 when they migrated from Macedonia to Istanbul, a turning point in the family's history. They held on to the family values attached to the initial family craftsmanship that had a persistent influence on the next generations' decisions to preserve traditional elements, despite the pressures for change due to environmental changes, and the closure and opening of new shops.

"It isn't actually a 5th generation brand, it is a 5th generation family profession. [...] It is special to have a brand with such strong history, having so many stories at hand is so valuable. If you want something to be persistent in business, you have to embed it within the family values" (GM, 5th generation; interview)

"There is such a thing as the 'Bake Case' culture, characterized by strong feelings of belonging and dedication" (Marketing Manager; interview)

"We make sure that century old family recipes are not forgotten, and old flavors are preserved" (GM, 5th generation; newspaper interview)

The family also continues producing the food at the same place where it is consumed, a custom emphasized on a sign on the wall: "We prepare here, we cook here", opening a store in a shopping center only when they could ensure preserving this traditional aspect.

"We took this offer because we were able to produce at the same place where we sell our products" (GM, 5th generation; interview)

The Revani Case, a restaurant founded in 1933 and run by the 3rd and 4th generations, also adopts a preservation approach to tradition. The family experienced extensive poverty during the founding stage, which has had a persistent influence on the following generations that strive to protect the values and beliefs of the founding family generation. The current generation rejected diverse business opportunities, such as opening a restaurant in the Ottoman Palace or developing a restaurant chain, as these would not have been in accordance with their family values and 
beliefs.

"This is a family craft built upon the talents of our migrated ancestors. In the end, it's a value of our family and it's our duty to ensure its prosperity across generations" (Purchasing Manager, 3rd generation; interview)

"Only those with money would go there. It would appeal to only a certain segment of the population. Here, you can see all kinds of people. We said, thank you, this is not our family's style. [...] Maybe you'll get rich, that's nice, but this is not how we've been educated, that is not our culture" (GM, 3rd generation; interview)

In line with the preservation approach, the current generation has continued to purchase meat from the same supplier for over 60 years since this practice is part of the family tradition.

"Even though it's more expensive we continue buying from them, this is a custom" (GM, 3rd generation; interview)

Revival. Our analysis shows that some family firms recognize that valuable elements of their tradition have faded or been lost, actively searching in their past and recovering components to revive their tradition. In the Smetana Case, a 2nd generation Russian restaurant founded in 1932 in Istanbul, Russian cuisine is part of the family tradition that had been abandoned due to the social and political developments that led to a substantial decrease in the Russian population in Istanbul. The family started reproducing certain recipes that had been forgotten for decades, readopting the traditional ways in which products were served. The relaunch of smetana, strogonoff, bilini caviar, karski, pashtet ${ }^{8}$, and home-made vodka are examples of products developed with these recuperated receipts. Smetana was purchased from a fish market until the end of the 70s, and when the supplier went out of business, the family stopped serving it. After some research in 1996, they started to produce their own, but reintroducing this product required deep research since written, formal recipes were lacking, and the ingredients were difficult to find. In line with the revival approach, the firm published two books on the restaurant's history and original recipes to celebrate the revived tradition.

"We made a change, but it wasn't about imposing a different character, maybe more than half of it was stuff that we used to do in the past. [...] It was a lot of work that led us to formalize those almost lost recipes" (GM, 2nd generation; interview)

\footnotetext{
${ }^{8}$ Smetana is Russian sour cream, one of the key ingredients in Russian cuisine. Strogonoff is a Russian dish of sautéed beef served in a sauce with smetana. Bilini is a Russian pancake. Karski is a Russian meat dish. Pashtet is a Russian pâté mostly prepared with beef, goose, or chicken liver.
} 
Another family firm in which tradition was abandoned and then revived is the Baklava Case, currently run by the 5 th and 6 th generations specialized in baklava $a^{9}$ production since 1820 . The exact origins of the family craftsmanship activity, which started before the official foundation of the family firm, were difficult to trace, even for the family, and the business was dispersed among many siblings throughout the generations. 1980 saw a military coup in Turkey and the new authorities set a fixed price for baklava. The family could not afford to sell at that price, as their costs were too high due to using high quality ingredients. The family stopped baklava production and, in the meantime, developed a new product, sütlü nuriye, replacing costly pistachios with cheaper walnuts, adding milk to increase the volume and decrease the price. Later, the family firm revived the original baklava while continuing the production of sütlü nuriye. In line with the revival approach, the 6th generation actively searched the past to trace their tradition through retrospective archival studies.

"For two years, they only sold this [sütlü nuriye] [...] It's a product that saved us at that time. [...] then baklava was brought back" (Production Manager, 6th generation; interview)

The Gazoz Case, a 4th generation family firm producing non-alcoholic beverages, is also an example of the revival approach to tradition. Founded in 1930 through a partnership, the family fully acquired the firm in 1957. Similarly to the Baklava Case, the family has been involved in the craft for seven generations, beyond the official founding date. The family firm's complex founding story made it difficult to trace the origins and stick to the founding values. Over time, the family firm has gained outstanding public recognition for its traditional gazoz - a carbonated drink. At that time, while all producers sold gazoz in standard bottles, the family developed a special design, soon known as the legendary bottle, then abandoned for quality issues. To revive its legacy, the family firm brought back the original gazoz bottle after a great deal of research.

"That bottle had a manufacturing defect that caused us losses in production... Nevertheless, the customers continuously demanded that bottle" (GM, 4th generation; interview)

"We thought about how we can adapt this bottle to today's technology, without deviating from the original concept [...] So we reintroduced the legendary bottle” (Production Planning Specialist, 3rd generation; interview)

\footnotetext{
${ }^{9}$ Baklava is a traditional Turkish dessert made of layers of filo pastry filled with chopped nuts and sweetened with syrup.
} 
Another example of this revival approach emerged from the Diary Case, a diary and notebook producer currently run by the 4th and 5th generation. Although the official founding date is recorded as 1892, the family started its business activities before this date. The traditional logo and fonts on the diaries were changed by the previous generation, a decision that the current generation regretted and decided to revive. The family firm also revived tradition by recovering the craftsmanship of diaries in the vintage style they used in 1920 and 1934 with the intent of creating a heritage collection including original covers in the Ottoman language.

"This [the heritage collection] is giving back to people our family's traditional feelings. We will bring back such traditional feelings in other practices to revive our family values and beliefs" $\left(G M, 5^{\text {th }}\right.$ generation; interview)

\section{Approach to Innovation}

Segregation. On investigating the approach to innovation, we identified some family firms in which current and new products and processes are segregated and treated as two different types of offerings. In these family firms, ongoing products are kept unaltered and new products or product lines are developed in parallel with the current offer. The cases adopting the segregation approach are characterized by iconic products that mark the family's history. The families pioneered the industry and gained an outstanding reputation through these breakthrough products that are assigned a special message and whose influence persists in current generations, perceived as an indispensable component of the family's identity.

In the Winery Case, the family firm was the first wine production facility in Turkey, and the wines produced in the founding period were imbued with a special message for the family that has endured to the current generation. Today, the Winery Case is innovative in terms of new product development, yet their classic wines are kept intact alongside innovative products.

"Glass Alpha and Villa Beta brands have been produced since the 30s. I have a specific attitude towards the products that I launched myself, and a different attitude towards the ones produced before me, as these communicate something very important to us" (Manager, $3^{\text {rd }}$ generation; interview)

Another example following the segregation approach is the Diary Case. The classic blackcovered diary was a breakthrough product at the time it was launched, widely used among the population for many years, and becoming a collection item. The title of the book the family firm 
published, The Big Family behind a Notebook, also reflects the significance of this product for the family that has gained an outstanding reputation through it.

“The black-covered diary made us who we are, it is special for us. We don't change anything with this one” (GM, 5th generation; interview)

The family firm has not made any changes to this product, but in parallel offers a wide range of new product lines using advanced technologies. An example is their newly developed notebook that in combination with a mobile application allows scanning and sending pages online. They also print QR codes inside the new products for a digital interface.

"Generations change so quickly. The old generation buys from you anyway, but you have to sell to the new generation, so you can carry the family business to the next generation" (Sales Manager; interview)

The Gazoz Case also embraces a segregation approach to innovation. As the family entered the beverage business in 1930, they created a secret formula, creating a product marketed as the legendary gazoz, a success when it was first launched.

“We didn't' make this title up. The 'legendary' title was already used by our customers, and we said why don't we use it" (GM, 3rd generation; interview)

"Beginning from its first launch, the legendary gazoz always had a special meaning for the family" (Book chapter on the family firm, Türk Markaları, 2013)

The family firm's current reputation is mainly based on the legendary gazoz, although many new products have been developed alongside it. In line with the segregation approach, the legendary gazoz was been kept intact and innovation activities are carried out in parallel to the core activity. Similarly, the Quartz Case is an example of segregation. From inception, the family has enjoyed an outstanding reputation with expertise in mechanical watches, and is dedicated to maintaining this reputation through offering quartz watches as a separate product line, unlike competitors who chose between the two.

"In the sector, it is said: They [the Quartz Case] are the capstone of mechanical watches" (Corporate Communications Manager, 4th generation; interview)

By introducing new products while keeping current ones intact, the family firm was able to continue conveying the messages their ancestors imbued in iconic products. This influence persists in the current generation, perceiving new technologies as threats against the bequest.

"Now there is a new threat, the smart watch. [...] We don't know how much it will affect us, we are getting ready 
for it" (GM, 3rd generation, interview)

Integration. Four family firms in our sample innovate by blending their current offering with novel solutions following an integration approach. These family firms do not have iconic products in their current offer, and therefore do not associate any specific message with their past products or process/technology. Consequently, they reinterpreted their traditional products in line with modern conditions, adopting new technologies to improve their traditional production. At the same time, protecting the essence of their business plays an important role in this approach to innovation.

An example following the integration approach to innovation is the Smetana Case. When the Russian population in Istanbul diminished due to various political developments, the family firm had to adapt. Differently from the Quartz Case, which also faced an environmental crisis but adopting a segregation approach, the Smetana Case integrated their Russian roots with the new conditions, developing new products targeting Turkish customers.

"When it was first founded, Russians were the target group. But then there were no Russians left, so we had to address new segments. [...] There may be certain changes in products, but this serves the purpose of adapting to changing conditions" (GM, 2nd generation; interview)

For example, roasted duck stuffed with apples is a characteristic Russian dish that is rather incompatible with Turkish cuisine. By replacing apples with eggplant and cooking the dish in a casserole, they made the dish more appealing to Turkish taste.

"Our biggest success in 75 years lies in our continuous adaptation to the conditions of the day" (GM, 2nd generation; personal writing)

Another example following the integration approach to innovation is the Baklava Case. Similar to the Smetana Case, they integrate current knowledge and experience in new product development. The family firm developed many variations of baklava by reinterpreting the current offer while combining it with new ideas, including baklava with almonds or chestnuts, different pastries made from the same dough, and baklava for people with celiac disease.

"It may be a cake, but it's always the same dough that is cut in different ways and becomes a new product" (Production Manager, 6th generation; interview)

The Revani Case is a further example of traditional products improved through the integration 
of new technologies. The family has maintained the same product line over many generations, never feeling the need to introduce new products. However, the current family generation feels comfortable with improving their products by integrating modern technologies.

"We have a wide variety of dishes. Over 100. We don't feel the need to introduce others. We used to beat revanilo with our hands, now the machine beats it, and it beats better" (GM, 3rd generation, interview)

"Of course, when doing this, we take great care to not degenerate an Ottoman dish by putting a sausage pizza next to it. (Manager, $4^{t}$ h generation; magazine interview)

In line with the integration approach to innovation, the Bake Case has blended its current offering with novel solutions, although striving not to alter its current production methods.

"We are very conservative with respect to some issues, very innovative with respect to others. For instance, we avoid prolonging the shelf-life in unnatural ways such as using additives or freezing the raw materials [...] But in terms of product, we have always been very innovative and change our offer frequently" (GM, 5th generation; interview)

Similar to the Gazoz Case, the Bake Case pioneered the introduction of new products in the bakery industry in Turkey. These new products included reinterpretations of their current offer in response to changing eating habits. For example, the family started to produce small single-serving versions of their cakes in response to changing consumption patterns. However, in contrast to the Gazoz Case, this family firm did not have in its current offer a product embodying special messages from the previous generation. As such, they were comfortable with integrating changes into their current products, albeit remaining loyal to their essence.

"I'm saying that freezing is something I would never do, but one day a technology may become available that doesn't at all affect the product. I cannot argue against it" (GM, 5th generation; interview)

\section{Family Firm Strategies to Manage the Tradition and Innovation Paradox}

Our analysis revealed that the innovation and tradition approaches of these family firms can be categorized in a $2 \times 2$ matrix of four types of equifinal strategies with which they manage the tradition and innovation paradox (see Figure 2).

Strategy 1: Protecting the Heritage. Two family firms in our sample, the Quartz and the Winery Cases, manage the paradox between tradition and innovation by combining the

${ }^{10}$ Revani is a traditional Turkish dessert. 
segregation approach to innovation with the preservation approach to tradition. We label this strategy protecting the heritage. In these family firms, iconic founders have a persistent influence on the current generation that views the business and its products as a means to protect family values, beliefs, and customs, and to continue the family craftsmanship. Thus, they consistently refuse to contaminate or alter the received bequest, deemed disrespectful to their origins. Family firms adopting this innovation strategy in our sample innovate alongside their bequest, simultaneously achieving two seemingly opposing objectives. First, they protect their tradition, serving as the glue that binds the family over many generations, as well as a source of unique value for customers. Second, innovation takes place outside the core traditional activity, boosting the development of products or processes outside the core activity.

The Winery Case has preserved its iconic wines for many generations while actively developing new products segregated from the traditional product line. In 1970, the family firm produced the first varietal wine in Turkey from a single grape variety. During the 1990s, the firm produced specialty wines by growing the most renowned grape varieties in Turkey. During the 2000s, they introduced a new series using native grape varieties in combination with universal grape varieties for the first time in Turkey. Similarly, if the Quartz Case had insisted on sticking to their traditional product line, it would not have survived. However, totally switching to quartz watches would also have resulted in the loss of family tradition. Unlike competitors adopting an either/or approach, the family continues producing mechanical watches alongside quartz watches.

"Some resisted, saying that they wouldn't do anything other than mechanical watches, some tried to switch to quartz. watches. [...] Our firm switched to 30\% mechanical watches, $70 \%$ quartz watches. Everybody says that cultural heritage must be protected. If I don't belong to today, it means I haven't protected the cultural heritage. [...] If I belong to today, it means I have protected the cultural heritage" (GM, 3rd generation; interview)

Strategy 2: Maintaining the Essence. Two family firms in our sample, the Revani and the Bake Cases, adopt an integration approach to innovation and a preservation approach to tradition. These family firms not only strive to preserve their past, but also use their tradition as a resource 
for their current offer. We label this strategy maintaining the essence. Here, specific products or production methods have not been assigned an exceptional message by the former generation, as in Strategy 1, although the current family generation carries on the values, beliefs, and customs of the previous family generation. Integrating tradition into new products and processes naturally calls for greater caution to maintain the essence of tradition.

For example, the Revani Case integrates novel technologies in traditional products only if the change does not affect their essence.

"If we're going to lose something with a change, we don't do it" (GM, 3rd generation; interview)

"We never forget our essence [...] we polish and brighten it" (GM, 3rd generation; documentary)

For the Bake Case, the combination of traditional products with novel technologies allows the firm to maintain its essence and develop a unique bundle of resources to enhance its competitive advantage. Our evidence shows that family members recognize the need to pursue innovation, and at the same time, carefully avoid undermining the core characteristics of their products shaped by the previous family generation.

Strategy 3: Restoring the Legacy. The Smetana and the Baklava Cases provide evidence for the combination of the integration approach to innovation and the revival approach to tradition, a strategy we label restoring the legacy. Family firms following this strategy recognize that the characteristics of the previous family generations in terms of values and beliefs have partly faded over time. Regretting the loss of tradition, current family generations search in the past to trace the tradition, completing the missing pieces by reinterpreting traditional products, processes, or designs through novel knowledge to restore the legacy. In this strategy, there is no sharp distinction between the past and the present, as both are combined through reinterpretation. Our evidence shows that family firms search in their past documents, memories, and customers to reinterpret the legacy into something new and coherent. At the same time, they follow modern technologies and conduct research on how these might be integrated into their legacy, avoiding solutions that distort their tradition. 
For example, the Smetana Case has a strong legacy in the past, but the current generation had to strive to revive the faded values of previous family generations. To restore what they possessed in the past, they refer to modern opportunities.

"Safeguarding the legacy of the past also involves carrying it to the future. We have always tried to benefit from modern opportunities. [...] As long as the messages of our products remain protected, making use of modern opportunities is favorable, indeed necessary" (GM, 2nd generation; interview)

Similarly, in the Baklava Case, introducing a product innovation took four years of research during which $R \& D$ engineers and craftsmen worked together to reinterpret baklava for people with diabetes. The decision to switch to a new production method related to whether the change was in accordance with the legacy they strove to restore.

"Machines only do the monkey work. [...] If you use machines, you will give up on some beauties. For instance, there are machines for slicing [...] If you use it, it hinders the dough from rising. We still use a knife. There are certain boundaries" (Manager, 6th generation; interview)

Strategy 4: Embracing Nostalgia. Finally, we observe that the last two family firms in our sample, the Diary and Gazos Cases, manage the paradox by combining a segregation approach to innovation with a revival approach to tradition. We label this strategy embracing nostalgia. In this strategy, nostalgia calls for a revival of the classic segregated from new products or processes, and the revival of tradition occurs in parallel to innovation. Our findings show that for family firms following this strategy, the influence of previous family generations is mostly evident in the inherent messages associated with the products they created. When traditional products are recovered, they are kept in their original nostalgic form. While searching the past to recover old products or processes, these family firms developed new innovative solutions in parallel. Through the simultaneous pursuit of segregation and revival, the distinction between the familial past and the future is remarkably sharp.

The Diary Case distinguishes between two different product lines that may be categorized as nostalgic and modern. Nostalgic products, such as the heritage collection or the new nostalgia and hatırat (memoirs) collections, have the purpose of reviving tradition, whereas the modern product lines, including the mobile application notebook or diaries with QR codes, serve the 
purpose of keeping up to date with modern times.

"We keep up with modern times, but we don't print the QR code on the classic diary. You shouldn't have to make a choice between the two, I think both are required" (GM, 5th generation; interview)

Worth noting is that in this strategy, family firms try not to cross a certain line in pursuing change, even with their modern product lines. For example, the Diary Case refuses to adopt English names, and the Gazos Case refuses to introduce alcoholic beverages.

"You shouldn't cross the line. What the line is, is actually not easily definable. When you take the product in your hands, you should be able to say that it is made by the Diary Case” (GM, 5th generation; interview)

"Some things are classic, you cannot change the classic, if you force it to change it will backfire. Years ago, I wanted to produce beer, my father said: 'Are you nuts? Your ancestors are all pilgrims. [...] I pass it on to my children, don't sell alcohol. That's tradition!" (GM, 3rd generation; interview)

\section{Discussion and Theory Elaboration}

We have undertaken an in-depth investigation of tradition and innovation in 8 longestablished family firms in relation to the family values, beliefs, customs, and practices pertaining to the messages that previous family generations imbued in the products and production methods. Our study shows that the use of tradition in family business innovation is much more complex and variegated than previously understood. Counterintuitively, our findings reveal that family firms can use innovation as a tool to protect or strengthen their tradition, and can revive their tradition to innovate. This suggests that family firms can still be innovative while strongly concerned with and anchored to tradition. To explain the adoption of the 4 strategies through which family firms can manage the tradition-innovation paradox, we searched the literature for existing theories that could account for the observations emerging from our data. We linked our empirical evidence to theory by abductively grounding our argument in imprinting theory (Marquis \& Tilcsik, 2013; Simsek et al., 2015) to build and refine the conceptual insights from case study research. Figure 3 illustrates our model, and following Steier (2001a, b), we present propositions based on our findings.

\section{Imprinting in Family Firms}

--- Insert Figure 3 here ---

Organizations' current behavior can reflect historical experiences, conditions, and constraints 
(Simsek, et al., 2015). We argue that family firms adopt elements of their family founding environment that persist beyond the founding phase. Specifically, imprinting is the process through which a focal entity develops characteristics that reflect prominent features of the environment, and such characteristics persist despite significant environmental changes in subsequent periods (Marquis \& Tilcsik, 2013; Stinchcombe, 1965). The founding stage is a key sensitive period for family firms (Johnson, 2007), as it marks the transition from being 'just a family' to becoming a new entity, with consequences for later life. Sensitive periods can emerge not only at the formation stage, when heroic ancestors start up the family business, but also at later stages in relation to turning points in the family history or a shift in the industry, market or society, such as emigration or institutional changes.

In line with Marquis and Tilcsik (2013), our evidence shows that current family generations in the business (imprinted entity) may be imprinted by the previous generation (imprinter) (Simsek et al., 2015), affecting family firm behavior (Rau, Werner, \& Schell, 2018). Stories about heroic grandfathers or how the family tradition was sustained through turbulent times may contribute to secondhand imprinting (Tilcsik, 2012), whereby imprinted values and beliefs are transferred across generations even long after the imprinters have passed away (Kammerlander et al., 2015). When family imprinting is not that strong, family tradition may be abandoned over time, and family firms have to actively search their past to trace their tradition (Katila, 2002). The lack of sensitive events marking the founding stage, or the dispersion of the business among siblings over generations, may hinder the persistence of such family imprinting (Marquis \& Tilcsik, 2013), fading the family values, beliefs, customs, and/or meanings the family attaches to products, production methods and practices.

\section{Family Imprinting Perspective on Managing the Tradition and Innovation Paradox}

We have identified two approaches to tradition and two approaches to innovation whose combination leads to four equifinal strategies through which family firms can manage the tradition-innovation paradox by protecting their heritage, maintaining the essence, restoring their 
legacy, or embracing nostalgia. Moreover, consistently with Steier (2017), our findings reveal that in approaching innovation, the current family generation is largely driven by what has been imprinted by the previous family generation. Consistent with imprinting theory, in family firms, the founder's beliefs and practices established during the founding stage become routinized, thereby long outlasting the founder's tenure (Marquis \& Tilcsik, 2013), and influencing the decision making process of the next family generation involved in the business. For those family firms whose values and beliefs have been preserved over time and passed down across generations through traditionalizing mechanisms (Simsek et al., 2015), tradition calls for preservation. Conversely, cases where such family values and beliefs have faded across generations require the current generation's more active efforts to search and revive tradition. Therefore, we propose:

Proposition 1: The more (less) previous family generations imprint family values and beliefs on the current generation, the more the current family generation in the family firm is likely to adopt a preservation (revival) approach to tradition.

Our findings also suggest that the founding family generation may imprint product signs intended as product textures, colors, tastes, materials or production methods - communicating messages to the firm's family members. In the long-established family firms we studied, the artisanal products are infused with family attachment, even personified as family members. For example, in the case of the founder's discovery or development of a breakthrough product where the family business subsequently acquires a strong reputation, the current family generation may carry a persistent mark related to that product or process (Marquis \& Tilcsik, 2013). In its approach to innovation, the current generation at the helm of the family firm is driven by the messages of those products launched by the founder or previous family generations, shaping the family business image over the years. Our evidence suggests that the current family generation adopts a segregation approach when recognizing an important message in the new products or processes the previous generations introduced, dividing iconic products or processes from new 
ones to avoid insulting the memory of their ancestors who created the firm and its reputation. Conversely, when the link to the message that the products or processes convey is not very strong, family firms build on their expertise and integrate it with current technologies and knowledge to innovate. Thus, we propose:

Proposition 2: The more (less) previous family generations imprint product signs (textures, colors, tastes, materials or production methods) on the current family generation, the more the current family generation in the firm is likely to adopt a segregation (integration) approach to innovation.

Our findings resonate with research on the key role of imprinting in family firms (Jaskiewicz et al., 2015; Pieper, Smith, Kudlats, \& Astrachan, 2015), particularly in the innovation process (Kammerlander et al., 2015). In a departure from prior research on family business from an imprinting perspective, we specify how differences in the content imprinted by the previous generation on the current family generation influence the family firm's approach to tradition and innovation, and the strategy adopted to manage the tradition-innovation paradox. Besides purely traditional and purely innovative companies, some family firms offer an ideal organizational setting to foster temporal symbiosis, which we define as an organization's simultaneous adoption of retrospective and prospective approaches to using its resources to concurrently perpetuate tradition and achieve innovation. In the family firms that we studied, the relationship between tradition and innovation is symbiotic, as they feed and nurture each other, each providing the conditions necessary for the other to continue to exist. Rather than opposing concepts, the outcome of modernization and traditional processes for family firms consists in an admixture wherein each derives a degree of support from the other (Gusfield, 1967). We draw on the biological metaphor of symbiosis to conceptualize the organizational capability to manage tensions between the past and future, overcoming their apparent conflict, and leading to positive interaction. Through the combination of retrospective and prospective approaches, the past and the future live closely together in the organization in the principle of mutualism, resembling the coexistence of dissimilar organisms in an ecosystem. As such, temporal symbiosis denotes the 
concomitance of tradition and innovation, as well as the close association through which they feed each other, leading to reciprocal benefits. Accordingly:

Proposition 3: Family firms can manage the tradition and innovation paradox by adopting four types of equifinal strategies based on their approach to tradition (preservation vs revival) and their approach to innovation (integration vs segregation).

Proposition 3a: The protecting the heritage strategy is most suitable when the family firm has a preservation approach to tradition and a segregation approach to innovation.

Proposition 3b: The maintaining the essence strategy is most suitable when the family firm has a preservation approach to tradition and an integration approach to innovation.

Proposition 3c: The restoring the legacy strategy is most suitable when the family firm has a revival approach to tradition and an integration approach to innovation.

Proposition 3d: The embracing nostalgia strategy is most suitable when the family firm has a revival approach to tradition and a segregation approach to innovation.

Through temporal symbiosis, family businesses can adopt different approaches to tradition and innovation that shape four equifinal strategies. Temporal symbiosis therefore emerges as a new firm capability that a family firm must be endowed with (or can develop) to adopt one of the four equifinal strategies to manage the tradition and innovation paradox, but does not guarantee that a family firm will adopt a tradition-innovation paradox management strategy. Formally stated:

Proposition 4: Temporal symbiosis is a necessary but insufficient condition for family firms to adopt one of the four strategies to manage the tradition and innovation paradox.

The four propositions, illustrated in Figure 3, summarize our proposed answer to the initial research question on how family firms manage the paradox between tradition and innovation.

\section{Contributions, Limitations and Future Research Directions}

Our study offers three main contributions, as well as avenues for future research. First, by revealing that tradition is a key element in family firm innovation, we contribute to knowledge on what makes family firm innovation distinctive (Calabrò et al., 2018; Röd, 2016). Through decades of knowledge and experience handed down across multiple generations, all family firms in our sample incorporate traditional elements in their business that interfere with their innovation activities in multiple ways. Products and production methods that would normally be 
prone to change are signs of the family history and identity originating from the past. As such, these products and production methods take on an ideological character that combined with the family values and beliefs influence the strategies that later generations adopt. A living tradition can provide resources for continuous adjustments to contemporary challenges, and family firm members might feel a sense of custodianship over their tradition's present and future prospects (Soares, 1997). Our findings contribute to the debate on tradition as a constraint or resource (Dacin et al., 2019) linked to innovation. By embracing an integrative perspective, we show that tradition is a significant and distinctive asset for family firm innovation (De Massis et al., 2016; Kammerlander et al., 2015) that sets boundaries to change, particularly in long-established family firms with a strong heritage. What is more, we contribute to advancing the concept of innovation through tradition (De Massis et al., 2016) by showing that firms can leverage not only traditional resources (e.g., family values and beliefs, product signs) to innovate but also innovative resources (e.g., new technologies, new knowledge, amongst others) to perpetuate tradition. Put differently, innovation can be the means by which tradition is preserved. Thus, counterintuitively, we foresee the possibility for organizations, particularly family firms, to pursue not only innovation through tradition but also "tradition through innovation".

Second, our investigation is relevant to the imprinting literature (Marquis \& Tilcsik, 2013), strongly intertwined with tradition since its inception (Stinchcombe, 1965; Tilcsik, 2012). Imprinting has been discussed in family business literature in relation to entrepreneurial legacy (Jaskiewicz et al., 2015), capturing the rhetorical reconstruction of past entrepreneurial achievements that are imprinted, transferred, and interpreted between and amongst generations (Hammond et al., 2016). Our study offers insights into how the family imprinting of previous generations can occur and shape the strategies of the current generation, shedding light on the traditionalizing mechanisms that allow persistence despite environment changes (Marquis \& Tilcsik, 2013). We distinguish between two different types of imprinting content (product signs, and family values and beliefs) illustrating their diverse persistence on the imprinted entity in 
relation to the tradition and innovation approaches and resulting strategies.

Third, our findings suggest that tradition and innovation are not necessarily contradictory, and learning to innovate in the presence of tradition is an important concern for family firms seeking to survive and thrive over generations (Lumpkin et al., 2008). By identifying the new temporal symbiosis construct and the types of strategies that family firms endowed with temporal symbiosis can adopt, we contribute to the family business literature by disentangling the two tensions behind a paradoxical behavior of family firms (e.g., Schuman et al., 2010), illustrating the compatibility between tradition and innovation. We contribute to family business literature by showing that family businesses cannot solely stick to tradition, which would result in losing competitiveness, or exclusively pursue innovation, which would erode their core and distinctive legacy. Our study instead suggests that moving from an either/or to a both logic (Collins \& Porras, 1994) is key for family firms to leverage their distinctive strengths and thrive. Building on our model, it would be interesting to investigate whether family firms are locked into our suggested strategies or whether there are forces that enable or prevent them from moving between the different strategies. Our temporal symbiosis construct highlights a new intervening factor in the strategies that family firms adopt to manage the tradition and innovation paradox. As such, we encourage future scholars to examine temporal symbiosis as a new type of firm capability related to innovation strategies, for instance, whether it is a static or dynamic capability (Eisenhardt \& Martin, 2000), and how it relates to other concepts characterizing family firm behavior, such as multitemporality - meeting both short- and long-term challenges (Le Breton-Miller \& Miller, 2011). By embracing a dynamic perspective, it would also be interesting to explore what factors may lead to variations in a firm's temporal symbiosis, how family firm managers may repeatedly and intentionally change their strategies over time (for instance, moving across the four quadrants in our matrix), and what determines such changes. Ideally, such studies would be longitudinal. Understanding the formation process by which a family firm that is not endowed with temporal symbiosis can develop this capability is another 
area ripe for future research.

Overall, emerging from our investigation is that a traditional organization is not necessarily opposed to meaningful change, since the past (tradition) may be invoked to achieve innovation (Kammen, 1991), and vice versa. This study therefore contributes to the mainstream innovation literature by illustrating that innovation is not always a challenge to tradition; likewise, tradition does not always hinder innovation. Tradition and innovation are inextricably linked, and neither can be adequately understood in isolation (Yerxa, 2017). In line with the imprinting perspective, we argue that organizational actors can either preserve or revive tradition, thereby assuming a more objective perspective on the past, and conceiving history as a collection of facts (Suddaby \& Foster, 2017). However, organizations may develop collective memory as ongoing rhetorical history (Foster, Suddaby, Minkus, \& Wiebe, 2011), relying on rich narratives to make sense of and impose meaning to their past, present, and future (Anteby \& Molnar, 2012). This stream of literature considers forgetting (voluntarily or otherwise) organizational knowledge as a critical first step in organizational renewal and change (de Holan \& Philipps, 2004). However, we show that family businesses can benefit from their ability to store knowledge, even if not relevant at that specific moment in time, and revive it when valuable. In other words, while organizations may intendedly forget, others may unintendedly remember, and this behavior can become a strategic advantage for innovation. Yet, remembering and forgetting are two sides of the memory concept (Anteby \& Molnar, 2012). While in our study we focus on what organizations remember, there are likely to be other aspects that these organizations may have forgotten. We thus call for future research on the process through which collective memory leads to remember or forget elements of the past to build tradition.

Our findings are based on data from long-established family firms where craftsmanship and artisanal capabilities are highly relevant. Tradition in these family firms influences their business operations. Although this sampling strategy enabled us to gather rich data on the interaction between tradition and innovation, it hinders generalizing our results to younger family firms and 
in other contexts. The former may not be exposed to the effects of tradition to the same extent as long-established family firms, and other aspects of tradition may be prevalent in these firms. Likewise, the magnitude of the influence of tradition (Steier, Chrisman, \& Chua, 2015) and the level of imprinting may vary across institutional contexts. Future studies could thus focus on younger family firms and/or family firms in other industries or geographic contexts to extend our study's findings and analyze the role of imprinting under these varying conditions.

Moreover, our study is mainly based on information from the latest generations involved in the family firms. Consequently, our insights into former generations are bound to the current generation's knowledge of the family and the firm's history. Although our informants were perfectly willing and able to recall the information provided, and we complemented primary data with secondary sources, we cannot rule out potential retrospective bias. Longitudinal investigations may further mitigate this potential bias and could also serve to explore whether an excess of tradition accumulated and persisting over time may exert a negative effect on innovation, or if a curvilinear relationship between tradition and innovation exists. Moreover, the reinterpretation of tradition over time (Hobsbawm, 2012) is likely to influence innovation behavior in family firms.

Finally, we theorize two types of imprinting content deriving from previous family generations and their distinct influence on the imprinted entity in relation to the tradition and innovation approaches, considering the multigenerational imprinting of founders and the family as amplifiers of the importance of tradition. However, we acknowledge that tradition can also be important for other types of firms, such as nonfamily craft businesses, and that sensitive periods are not only linked to firm foundation. Future research could explore other imprinting content and the possible impact on family firm behavior. In addition, we focus on family businesses, but acknowledge the growing studies that instead examine "business families" (e.g., Le BretonMiller \& Miller, 2018), i.e., enterprising families that typically own a portfolio of businesses operating in multiple industries and even multiple national markets. If taking a business family 
rather than a family business (i.e., firm) perspective, other elements of tradition, such as the "entrepreneurial mindset" (McGrath \& MacMillan, 2000) of previous family generation members, may emerge as a new type of content that could be imprinted on the current family generation. We thus welcome future studies that examine the implications of such perspective on our study's findings. Furthermore, it would be interesting to understand whether and how imprinting dynamics occur in other types of organizations, such as centenary nonfamily firms characterized by a long history or other types of organizations without family involvement, and how these dynamics differ.

\section{Conclusion}

Family firms are anchored to their tradition but are required to innovate to become and remain competitive. The tension between tradition and innovation gives rise to a paradox whereby family firms cannot strengthen one without compromising the other. Our abductive analysis shows that family firms can manage such paradox through four strategies, encouraging family business owners, managers, and advisors to consider family imprinting as an important aspect to understand how family firms can concurrently achieve innovation and perpetuate tradition.

\section{References}

Adner, R., \& Snow, D. (2010). Old technology responses to new technology threats: Demand heterogeneity and technology retreats. Industrial and Corporate Change, 19(5), 1655-1675.

Andersson, T., Carlsen, J., \& Getz, D. (2002). Family business goals in the tourism and hospitality sector: Case studies and cross-case analysis from Australia, Canada, and Sweden. Family Business Review, 15, 89-108.

Ankara Chamber of Commerce (2005). Aile şirketleri: Değişim ve süreklilik. Retrieved from http://www.aso.org.tr/kurumsal/media/kaynak/TUR/yayinlarimiz/ailesirketleri.pdf.

Anteby, M., \& Molnar, V. (2012). Collective memory meets organizational identity: Remembering to forget in a firm's rhetorical history. Academy of Management Journal, 55(3), 515-540.

Atabaki, T., \& Brockett, G.D. (2009). Ottoman and republican Turkish labour history: An introduction. International Review of Social History, 54(17), 1-17.

Bugra, A. (1994). State and business in modern Turkey: A comparative study. Albany, NY: State University of New York Press.

Calabrò A., Vecchiarini M., Gast J., Campopiano G., De Massis A., \& Kraus S. (2018). Innovation in family firms: A systematic literature review and guidance for future research. International Journal of Management Reviews. In press. 
Chirico, F., Criaco, G., Baù, M., Naldi, L., Gomez-Mejia, L. R., \& Kotlar, J. (2018). To patent or not to patent: That is the question. Intellectual property protection in family firms. Entrepreneurship Theory and Practice, https://doi.org/10.1177/1042258718806251.

Chrisman, J.J., Chua, J., De Massis, A., Frattini, F., \& Wright, M. (2015). The ability and willingness paradox in family firm innovation. Journal of Product Innovation Management, $32(3), 310-318$.

Chrisman, J.J., Chua, J.H., Pearson, A.W., \& Barnett, T. (2012). Family involvement, family influence, and family-centered non-economic goals in small firms. Entrepreneurship Theory and Practice, 36(2), 267-293.

Chrisman, J.J., Hofer, C.W., \& Boulton, W.B. (1988). Toward a system for classifying business strategies. Academy of Management Review, 13(3), 413-428.

Chrisman, J.J., Sharma, P., Steier, L.P., \& Chua, J.H. (2013). The influence of family goals, governance, and resources on firm outcomes. Entrepreneurship Theory and Practice, 37(6), 1249-1261.

Classen, N., Van Gils, A., Bammens, Y., \& Carree, M. (2012). Accessing resources from innovation partners: The search breadth of family SMEs. Journal of Small Business Management, 50(2), 191-215.

Collins, J., \& Porras, J. (1994). Built to last: Successful habits of visionary companies. New York: Harper Business.

Dacin, M.T. \& Dacin, P.A. (2008). Traditions as institutionalized practice: Implications for deinstitutionalization. In R. Greenwood, C. Oliver, K. Sahlin, \& R. Sudd (Eds.), The Sage Handbook of Organizational Institutionalism. London: Sage. pp. 327-351.

Dacin, M.T., Dacin, P.A., \& Kent, D. (2019). Tradition in organizations: A custodianship framework. Academy of Management Annals, 13(1), 342-373.

Dacin, M.T., Munir, K., \& Tracey, P. (2010). Formal dining at Cambridge colleges: Linking ritual performance and institutional maintenance. Academy of Management Journal, 53(6), 1393-1418.

Damanpour, F. (1991). Organizational innovation: A meta-analysis of effects of determinants and moderators. Academy of Management Journal, 34(3), 555-590.

de Holan, P. M., \& Phillips, N. (2004). Remembrance of things past? The dynamics of organizational forgetting. Management Science, 50(11), 1603-1613.

De Massis, A., Audretsch, D., Uhlaner, L., \& Kammerlander, N. (2018). Innovation with limited resources: Management lessons from the German Mittelstand. Journal of Product Innovation Management, 35(1), 125-146.

De Massis, A., Frattini, F., \& Lichtenthaler, U. (2013). Research on technological innovation in family firms: Present debates and future directions. Family Business Review, 26(1), 10-31.

De Massis, A., Frattini, F., Pizzurno, E., \& Cassia, L. (2015). Product innovation in family versus nonfamily firms: An exploratory analysis. Journal of Small Business Management, 53(1), 136.

De Massis, A., \& Kotlar, J. (2014). The case study method in family business research: Guidelines for qualitative scholarship. Journal of Family Business Strategy, 5(1), 15-29.

De Massis, A., Kotlar, J., Frattini, F., Messeni Petruzzelli, A., \& Wright, M. (2016). Innovation through tradition: Lessons from innovative family businesses and directions for future research. Academy of Management Perspectives, 30(1), 93-116.

Diaz-Moriana, V., Clinton, E., Kammerlander, N., Lumpkin, G. T., \& Craig, J. B. (2018). Innovation motives in family firms: A transgenerational view. Entrepreneurship Theory and Practice, https://doi.org/10.1177/1042258718803051.

Dieleman, M. (2018). Reaping what you sow: The family firm innovation trajectory. Journal of Family Business Strategy, In press, https://doi.org/10.1016/j.jfbs.2018.03.003.

Dion, D., \& Arnould, E. (2011). Retail luxury strategy: Assembling charisma through art and magic. Journal of Retailing, 87(4), 502-520. 
Draucker, C.B., Martsolf, D.S., Ross, R., \& Rusk, T.B. (2007). Theoretical sampling and category development in grounded theory. Qualitative Health Research, 17(8), 1137-1148.

Eisenhardt, K. M. (1989). Building theories from case study research. Academy of Management Review, 14(4), 532-550.

Eisenhardt, K.M., \& Graebner, M.E. (2007). Theory building from cases: Opportunities and challenges. Academy of Management Journal, 50(1), 25-32.

Eisenhardt, K.M., \& Martin, J.A. (2000). Dynamic capabilities: What are they? Strategic Management Journal, 21(10-11), 1105-1121.

European Commission (2008). Overview of family business relevant issues. Retrieved from http://ec.europa.eu/growth/smes/promoting-entrepreneurship/we-work-for/familybusiness/index_en.htm.

Erdemir, A. (2005). Tradition and modernity: Alevis' ambiguous terms and Turkey's ambivalent subjects. Middle Eastern Studies, 41(6), 937-51.

Fiese, B.H., Tomcho, T.J., Douglas, M., Josephs, K., Poltrock, S., \& Baker, T. (2002). A review of 50 years of research on naturally occurring family routines and rituals: Cause for celebration? Journal of Family Psychology, 16(4), 381-390.

Fletcher, D., De Massis, A., \& Nordqvist, M. (2016). Qualitative research practices and family business scholarship: A review and future research agenda. Journal of Family Business Strategy, 7(1), 8-25.

Foster, W. M., Suddaby, R., Minkus, A., \& Wiebe, E. (2011). History as social memory assets: The example of Tim Hortons. Management \& Organizational History, 6(1), 101-120.

Global Innovation Index (2016). Global Innovation Index 2016: Winning with Global Innovation. Ithica, New York: Cornell University, INSEAD, WIPO. Retrieved from https://www.globalinnovationindex.org/userfiles/file/reportpdf/gii-full-report-2016-v1.pdf.

Gusfield, J.R. (1967). Tradition and modernity: Misplaced polarities in the study of social change. American Journal of Sociology, 72(4), 351-362.

Hammond, N.L., Pearson, A.W., \& Holt, D.T. (2016). The quagmire of legacy in family firms: Definition and implications of family and family firm legacy orientations. Entrepreneurship Theory and Practice, 40(6), 1209-1231.

Harrison, R. (2013) Heritage: Critical approaches. Routledge, Abingdon and New York.

Hibbert, P., \& Huxham, C. (2010). The past in play: Tradition in the structures of collaboration. Organization Studies, 31(5), 525-554.

Hobsbawm, E. (2012). Introduction. In E. Hobsbawm, \& T. Ranger (Eds.), The invention of tradition. Cambridge: Cambridge University Press, pp. 1-14.

Hofstede, G. (1980) Culture's consequences: International differences in work-related values, Sage: Newbury Park, CA.

Ingram, A.E., Lewis, M.W., Barton, S., \& Gartner, W.B. (2016). Paradoxes and innovation in family firms: The role of paradoxical thinking. Entrepreneurship Theory and Practice, 40(1), 161-176.

ITO (2013). Türkiye'nin ve İstanbul'un asırlık şirketleri. Istanbul Ticaret Odası Ekonomik ve Sosyal Tarih Yayınları, Istanbul.

Jaskiewicz, P., Combs, J.G., \& Rau, S.B. (2015). Entrepreneurial legacy: Toward a theory of how some family firms nurture transgenerational entrepreneurship. Journal of Business Venturing, 30(1), 29-49.

Johnson, V. (2007). What is organizational imprinting? Cultural entrepreneurship in the founding of the Paris Opera. American Journal of Sociology, 113(1), 97-127.

Kadioğlu, A. (1996). The paradox of Turkish nationalism and the construction of official identity. Middle Eastern Studies, 32(2), 177-193.

Kağıtçıbaşı, C. (1996). Family and human development across cultures: A view from the other side. Hillsdale, NJ: Erlbaum. 
Kammen, M. (1991). Mystic chords of memory: The transformations of tradition in American culture. New York: Knopf.

Kammerlander, N., Dessi, C., Bird, M., Floris, M., \& Murru, A. (2015). The impact of shared stories on family firm innovation: A multicase study. Family Business Review, 28(4), 332 354.

Katila, R. (2002). New product search over time: Past ideas in their prime? Academy of Management Journal, 45(5), 995-1010.

Kerslake, C., Öktem, K., \& Robins, P. (2010). Turkey's engagement with modernity: Conflict and change in the twentieth century. Basingstoke: Palgrave Macmillan.

Le Breton-Miller, I. \& Miller, D. (2011). Commentary: Family firms and the advantage of multitemporality. Entrepreneurship Theory and Practice, 35(6), 1171-1177.

Le Breton-Miller, I. \& Miller, D. (2018). Beyond the firm: Business families as entrepreneurs. Entrepreneurship Theory and Practice, 42(4), 527-536.

Lewis, M.W. (2000). Exploring paradox: Toward a more comprehensive guide. Academy of Management Review, 25(4), 760-776.

Linnekin, J.S. (1983). Defining tradition: Variations on the Hawaiian identity. American Ethnologist, 10(2), 241-252.

Locke, K.D., Golden-Biddle, K., \& Feldman, M. (2008). Making doubt generative: Rethinking the role of doubt in the research process. Organization Science, 19, 907-918.

Lumpkin, G.T., Martin, W., \& Vaughn, M. (2008). Family orientation: Individual-level influences on family firm outcomes. Family Business Review, 21(2), 127-138.

Marquis, C. \& Tilcsik, A. (2013). Imprinting: Toward a multilevel theory. Academy of Management Annals, 7(1), 195-245.

Mazzelli, A., Kotlar, J., \& De Massis, A. (2018). Blending in while standing out: Selective conformity and new product introduction in family firms. Entrepreneurship Theory and Practice, 42(2), 206-230.

McGrath, R.M. \& McMillan, I. (2000). The entrepreneurial mindset: Strategies for continuously creating opportunity in an age of uncertainty. Boston: Harvard Business School Press.

Messeni Petruzzelli, A. \& Albino, V. (2012). When tradition turns into innovation. How firms can create and appropriate value through tradition. Oxford, UK: Woodhead Publishing Limited.

Miller, D., Steier, L., \& Le Breton-Miller, I. (2003). Lost in time: Intergenerational succession, change, and failure in family business. Journal of Business Venturing, 18(4), 513-531.

Moores, K. \& Barrett, M. (2002). Profiles and patterns that work. In Learning family Business: Paradoxes and pathways. Aldershot, Ashgate: 131-149.

Oliver, C. (1992). The antecedents of deinstitutionalization. Organization Studies, 13(4), 563588.

Pieper, T.M., Smith, A.D., Kudlats, J., \& Astrachan, J.H. (2015). The persistence of multifamily firms: Founder imprinting, simple rules, and monitoring processes. Entrepreneurship Theory and Practice, 39(6), 1313-1337.

Radikal (2011). İşte Türkiye'nin asırlı 18 aile şirketi. Available at: http://www.radikal.com.tr/ekonomi/iste-turkiyenin-asirlik-18-aile-sirketi-1036043/.

Ranson, B. (1989). Craftwork, ideology and the craft life cycle. Journal of Design History, 2(2/3), 77-92.

Rasaba, A., \& Larabee, S. (2008). The rise of political Islam in Turkey. Washington DC: Rand Corporation.

Rau, S.B., Werner, A., \& Schell, S. (2018). Psychological ownership as a driving factor of innovation in older family firms. Journal of Family Business Strategy, https://doi.org/10.1016/j.jfbs.2018.03.001. 
Rauch, A., Wiklund, J., Lumpkin, G. T., \& Frese, M. (2009). Entrepreneurial orientation and business performance: An assessment of past research and suggestions for the future. Entrepreneurship Theory and Practice, 33(3), 761-787.

Renda, G., \& Kortepeter, C.M. (Eds.). (1986). The transformation of Turkish culture: The Atatürk legacy. Kingston Press.

Röd, I. (2016). Disentangling the family firm's innovation process: A systematic review. Journal of Family Business Strategy, 7(3), 185-201.

Rondi, E., De Massis, A., \& Kotlar, J. (2018). Unlocking innovation potential: A typology of family business innovation postures and the critical role of the family system. Journal of Family Business Strategy, https://doi.org/10.1016/j.jfbs.2017.12.001.

Schultz, M., \& Hernes, T. (2013). A temporal perspective on organizational identity. Organization Science, 24(1), 1-21.

Schuman, A., Stutz, S., \& Ward, J. (2010). Family business as paradox. New York: Palgrave.

Shaw, S.J. \& Shaw, E.K. (1977). History of the Ottoman Empire and Modern Turkey: Volume 2, reform, revolution, and republic: The rise of Modern Turkey 1808-1975 (Vol. 11). Cambridge University Press.

Shils, E. (1971). Tradition. Comparative Studies in Society and History, 13(2), 122-159.

Shoham, H. (2011). Rethinking tradition: From ontological reality to assigned temporal meaning. European Journal of Sociology, 52(2), 313-340.

Simsek, Z., Fox, B.C., \& Heavey, C. (2015). "What's past is prologue". A framework, review, and future directions for organizational research on imprinting. Journal of Management, 41(1), 288-317.

Smith, K.K., \& Berg, D.N. (1987). Paradoxes of group life: Understanding conflict, paralysis, and movement in group dynamics. Jossey-Bass.

Smith, W.K., \& Lewis, M.W. (2011). Toward a theory of paradox: A dynamic equilibrium model of organizing. Academy of Management Review, 36(2), 381-403.

Soares, J.A. (1997). A reformulation of the concept of tradition. International Journal of Sociology and Social Policy, 17(6), 6-21.

Steier, L. (2001a). Family firms, plural forms of governance, and the evolving role of trust. Family Business Review, 14(4), 353-367.

Steier, L. (2001b). Next-generation entrepreneurs and succession: An exploratory study of modes and means of managing social capital. Family Business Review, 14(3), 259-276.

Steier, L. (2017). Family enterprises as adaptive systems: The creation, organisation and evolution of homesteader farm families in Canada 1913-2017. Working paper.

Steier, L.P., Chrisman, J.J., \& Chua, J.H. (2015). Governance challenges in family businesses and business families. Entrepreneurship Theory and Practice, 39(6), 1265-1280.

Steier, L. P., \& Greenwood, R. (2000). Entrepreneurship and the evolution of angel financial networks. Organization Studies, 21(1), 163-192.

Stinchcombe, A.L. (1965). Organizations and social structure. Handbook of Organizations, 44(2), 142-193.

Suddaby, R., \& Foster, W.M. (2017). History and Organizational Change. Journal of Management, 43(1), 19-38.

Tilcsik, A. (2012). Remembrance of things past: Individual imprinting in organizations. Cambridge, MA: Harvard University.

Türk Markaları (2013). Reklamcılık Vakfi Yayınları, İstanbul, Turkey.

Vyas, K. (1991) The designer and the socio-technology of small production. Journal of Design History, 4(3), 187-210.

Voyatzaki, M. (2013). Handling tradition for a systemic innovation. Journal of Architecture and Urbanism, 37(4), 231-238.

Weber, M. (1982). General economic history. New Brunswick: Transaction. 
Weber, K., \& Dacin, M.T. (2011). The cultural construction of organizational life: Introduction to the special issue. Organization Science, 22(2), 287-298.

Woolley, M. (2011). Beyond control: Rethinking industry and craft dynamics. Craft Research, 2(1), 11-36.

Yerxa, D.A. (2017). Are innovation and tradition incompatible? Available at: https://www.bigquestionsonline.com/2017/01/04/are-innovation-tradition-incompatible/.

Yin, R.K. (2003). Applications of case study research. Thousand Oaks, CA: Sage.

Zellweger, T.M., Chrisman, J.J., Chua, J.H., \& Steier, L.P. (2018). Social structures, social relationships, and family firms. Entrepreneurship Theory and Practice. In press. 
Table 1

Description of Cases and Data Sources

\begin{tabular}{|c|c|c|c|c|c|c|c|}
\hline Firm & Industry & $\begin{array}{l}\text { Founded } \\
\text { in }\end{array}$ & $\begin{array}{c}\text { Generation } \\
\text { active in } \\
\text { management }\end{array}$ & $\begin{array}{c}\begin{array}{c}\text { \# of } \\
\text { employees }\end{array} \\
\text { el }\end{array}$ & Archival Data & Observation & $\begin{array}{l}\text { \# of interviews; transcript length } \\
\text { Role in the business (Role in the family) }\end{array}$ \\
\hline Bake & $\begin{array}{l}\text { Bakery \& } \\
\text { restaurant }\end{array}$ & 1836 & 5th & 315 & $\begin{array}{l}\text { Company webpage } \\
\text { Newspaper/magazine interviews (8) } \\
\text { TV interviews (8): } 125 \mathrm{~min} . \\
\text { Videos published by the family firm (24): } 170 \mathrm{~min} . \\
\text { Documentary about the family firm (1): } 20 \mathrm{~min} .\end{array}$ & $\begin{array}{l}\text { Field visit } \\
\text { Photos of signs, slogans, objects }\end{array}$ & $\begin{array}{l}\text { 2; } 25 \text { pages } \\
-5 \text { th generation GM (Daughter of previous } \\
\text { GM) } \\
\text { - Nonfamily Marketing Manager }\end{array}$ \\
\hline Baklava & $\begin{array}{l}\text { Baklava } \\
\text { production }\end{array}$ & 1820 & 5th \& 6th & 120 & $\begin{array}{l}\text { Company webpage } \\
\text { Company press releases (27) } \\
\text { Newspaper/magazine interviews (12) } \\
\text { TV interviews with family members: } \\
\text { Documentary about the family firm (1): } 17 \mathrm{~min} . \\
\text { CDs about baklava production (2) received from } \\
\text { family members }\end{array}$ & $\begin{array}{l}\text { Field visit } \\
\text { Visit to production site } \\
\text { Photos of signs, products } \\
\text { Informal conversations with 5th } \\
\text { generation GM and nonfamily employees }\end{array}$ & $\begin{array}{l}\text { 2; } 21 \text { pages } \\
-6 \text { th generation Production Manager (Son of } \\
\text { current GM) } \\
-6 \text { th generation Manager (Daughter of current } \\
\text { GM) }\end{array}$ \\
\hline Diary & $\begin{array}{l}\text { Diary and } \\
\text { notebook } \\
\text { production }\end{array}$ & 1892 & 4th \& 5th & 6 & $\begin{array}{l}\text { Company webpage } \\
\text { Book chapter about the family firm written by } \\
\text { Turkish History Association: } 8 \text { pages } \\
\text { Booklet published about the history of the family } \\
\text { firm received from informants: } 27 \text { pages } \\
\text { Detailed product catalogue: } 46 \text { pages } \\
\text { Newspaper commercials: } 2 \text { pages } \\
\end{array}$ & $\begin{array}{l}\text { Field visit } \\
\text { Photos of signs, products, objects, } \\
\text { documents, pictures } \\
\text { Collection of sample products as artifacts }\end{array}$ & $\begin{array}{l}\text { 3; } 35 \text { pages } \\
-5 \text { th generation GM (Daughter of previous } \\
\text { GM) } \\
\text { - Nonfamily Sales Manager } \\
\text { - Nonfamily Assistant Sales Manager }\end{array}$ \\
\hline Gazoz & $\begin{array}{l}\text { Beverage } \\
\text { production }\end{array}$ & 1930 & 3rd \& 4th & 900 & $\begin{array}{l}\text { Company webpage } \\
\text { Newspaper/magazine interviews (6) } \\
\text { Company press releases (30) } \\
\text { TV commercials (7) } \\
\text { Book chapter about the family firm: } 32 \text { pages } \\
\text { Detailed product catalogue: } 55 \text { pages }\end{array}$ & $\begin{array}{l}\text { Field visit } \\
\text { Visit to production site } \\
\text { Photos of signs, products, bottle } \\
\text { collections, photo collections, objects, } \\
\text { pictures, archives, machines } \\
\text { Informal conversations with nonfamily } \\
\text { employees }\end{array}$ & $\begin{array}{l}\text { 2; } 28 \text { pages } \\
\text { - 3rd generation GM (Son of previous GM) } \\
\text { - 4th generation Production - Planning } \\
\text { Specialist (Son of current GM) }\end{array}$ \\
\hline Quartz & $\begin{array}{l}\text { Watch sales } \\
\text { and service }\end{array}$ & 1889 & 3 rd \& 4th & 13 & $\begin{array}{l}\text { Company webpage } \\
\text { Magazine interviews (2): } 6 \text { pages } \\
\text { TV interview with general manager (1): } 12 \text { min. } \\
\text { Videos recorded by general manager (3): } 12 \text { min. } \\
\text { Personal watch blog of the GM (120 posts) }\end{array}$ & $\begin{array}{l}\text { Field visit } \\
\text { Interactions with customers }\end{array}$ & $\begin{array}{l}\text { 3; 41 pages } \\
\text { - 3rd generation GM (Son of previous GM) } \\
\text { - 4th generation Corporate Communications } \\
\text { Manager (Daughter of current GM) } \\
\text { - 4th generation Sales Manager (Nephew of } \\
\text { current GM) }\end{array}$ \\
\hline Revani & Restaurant & 1933 & 3 rd \& 4th & 53 & $\begin{array}{l}\text { Company webpage } \\
\text { Newspaper/magazine interviews (8) }\end{array}$ & $\begin{array}{l}\text { Field visit } \\
\text { Visit to the kitchen } \\
\text { Photos of signs, menus, dishes } \\
\text { Interactions with customers } \\
\end{array}$ & $\begin{array}{l}\text { 2; 32 pages } \\
\text { - 3rd generation GM (Son of previous GM) } \\
\text { - 3rd generation Purchasing Manager (Brother } \\
\text { of current GM) }\end{array}$ \\
\hline Smetana & Restaurant & 1932 & 2nd & 10 & $\begin{array}{l}\text { Company webpage } \\
\text { Newspaper/magazine interviews (2) } \\
\text { Book published by family firm: } 119 \text { pages } \\
\text { Personal writings of the general manager: } 6 \text { pages }\end{array}$ & Field visit & $\begin{array}{l}\text { 2; } 30 \text { pages } \\
\text { - 2nd generation GM (Son of previous GM) } \\
\text { - Retired manager (Mother of current GM) }\end{array}$ \\
\hline Winery & $\begin{array}{l}\text { Wine } \\
\text { production }\end{array}$ & 1926 & 2nd \& 3rd & 400 & $\begin{array}{l}\text { Company webpage } \\
\text { TV interview (1): } 23 \text { min. } \\
\text { Newspaper/magazine interviews (7) }\end{array}$ & $\begin{array}{l}\text { Field visit } \\
\text { Interactions with nonfamily employees }\end{array}$ & $\begin{array}{l}\text { 1; } 20 \text { pages } \\
- \text { 3rd generation Manager (Daughter of } \\
\text { current GM) }\end{array}$ \\
\hline
\end{tabular}


Table 2

Approaches to Tradition and Innovation: Selected Evidence

Aggregate Dimension: Approach to Tradition

\section{Second-Order Selected Evidence on First-Order Categories}

Themes

\section{Preservation Memorializing iconic founders}

Everything during my grandfather's time was done for the first time in Turkey. New grapes, new ways of making wine [...] He brought grape varieties for the first time to Turkey (Manager, Winery Case)

He was such a strong person. After the migration, it was times of poverty and Turkey just started developing. They've been through extreme poverty (GM, Revani Case) The words my grandfather told my father, and my father passed on to me: 'Do not sell a product you wouldn't eat yourself' (Newspaper Interview, GM, Bake Case) I don't remember my grandfather very much, but I know him from what my father has told me (GM, Quartz Case)

Holding on to the culture of family craftsmanship

We are the first and oldest winemakers in Turkey. We have been winemakers for three generations (Manager, Winery Case)

Our grandfathers, both on my mother's and father's side, have been involved in this craft for many years. This is a very long-established family craft (Purchasing Manager, Revani Case)

Our mission is to ensure the survival of the bakery culture (GM, Bake Case)

What excites me most is being able to continue on the same theme (GM, Quartz Case)

Sustaining family values, beliefs, and customs

Among our family values, we also have our past, we always emphasize it (Manager, Winery Case)

We said it's more important to protect this place and the values that our family has attached to it (GM, Revani Case)

We were reluctant to open up a store in the shopping center, mainly because we have to produce at the same place where we sell our product (GM, Bake Case)

My customer said: I inherited this watch from my grandfather. It's very valuable, I can't entrust it to anyone. I said: I inherited this firm from my grandfather, you can entrust it to me (GM's Personal Blog, Quartz Case)

Revival Regretting the loss of tradition

For the sake of reviving forgotten and abandoned values (GM, Smetana Case)

After the collapse of the Ottoman Empire, Palace cuisine was messed up and baklava almost vanished (Newspaper Interview, 5th generation GM, Baklava Case)

I think eliminating the traditional logo and fonts was an unnecessary mistake (GM, Diary Case)

After a while, unfortunately, the bottle had to be changed due to huge losses in production (GM, Gazoz Case)

Searching in the past to trace tradition

Information was collected from old customers, all these little pieces of information were used to complete the puzzle (GM, Smetana Case)

We are working together with the History Foundation, we are doing retrospective archival studies (Production Manager, Baklava Case)

[...] tracing our historical roots (GM, Diary Case)

This place is seriously a museum. We collected old bottles, old photographs (GM, Gazoz Case)

\section{Recovering tradition}

Forgotten and lost gastronomic values have been revived one by one through extensive effort (GM's personal writings, Smetana Case)

After the fixed price policy was over, baklava was brought back (Manager, Baklava Case)

Therefore, we made corrections to go back to the original form our business was born with (GM, Diary Case)

The legendary glass bottle which was used between 1965-1980 was relaunched in 2004 and received incredible appreciation from customers (Press Release, Nonfamily Vice Chairman, Gazoz Case) 


\section{Second- $\quad$ Selected Evidence on First-Order Categories \\ Order}

Themes

Segregation Holding on to iconic products

It feels like they're my older brothers. Although I manage them, that's something different (Manager, Winery Case).

But in addition to these, there were some products through which the Diary Case would become known in the following century, these products would also become its area of expertise (Document of the Turkish History Association, Diary Case)

The formula which is still kept secret carefully to this date is a pillar of the brand (Book, Gazoz Case)

Our firm, which is specialized in mechanical watches, has continued its existence although it was affected when Quartz watches dominated the sector (Magazine Interview, GM, Quartz Case)

\section{Distinguishing between different types of offerings}

For instance, I created Delta [a wine brand] from scratch. I feel much more comfortable there about introducing changes (Manager, Winery Case)

Here you bring back the tradition. [...] Here you catch up with technology, fashion, innovation. This is about traditional values, the other is purely innovative (GM, Diary Case) Gazoz has a distinctive place within our family firm, which has survived until this date thanks to the invention of the formula of gazoz by my father in 1932 . This formula is still kept secret (Magazine Interview, GM, Gazoz Case)

Our firm switched to $30 \%$ mechanical watches, $70 \%$ quartz watches (GM, Quartz Case)

\section{Integration Reinterpreting traditional products to suit to modern conditions}

We combined spices with orange, another health remedy. We created Winter Baklava for our customers looking for alternatives to classic baklava (Company Press Release, GM, Baklava Case)

We reinterpret classic dishes in modern ways to make them better suited to current taste (GM's personal writings, Smetana Case)

For example, we usually cook pilaki with beans. A Greek customer once requested we cook pilaki with chickpeas. We tried it and now we serve it every day. But we still use the classic recipe, changes may happen only in some ingredients like this. The way you make the pilaki is the same (Purchasing Manager, Revani Case)

Eating habits started to change in Turkey. We started to produce small single-serving version of our cakes (GM, Bake Case)

Improving traditional production through the adoption of new technologies

Of course we benefit from technology. Mainly for improving hygiene and sterilization. We use new methods to isolate air, we use science in sterilization. Diabetics couldn't eat baklava. We developed a syrup, it took four years of R\&D in which engineers and craftsmen worked together (Production Manager, Baklava Case)

The reproduction of homemade Smetana was even better than before. It ensured that Smetana did not melt on warm ingredients and preserved its shape for a long time (GM, Smetana Case)

Thanks to cooling technologies, the continuity of ice-cream production is made possible. Sheep's milk is the basis of our ice-cream. Now we can use our milk throughout the year (Magazine interview, Family manager, Revani Case)

I'm saying that freezing is something I would never do, but one day a technology may become available that doesn't at all affect the product. I cannot argue against it (GM, Bake Case)

\section{Protecting the essence while innovating}

When producing low-glycemic dough for diabetic patients, I would not agree to launch it if it is too stiff. That would be losing the essence of baklava in which we believe (Production Manager, Baklava Case)

When launching something new, we choose products that are compatible with our past, we did not go for a marginal concept (GM, Smetana Case)

Kitchen tools get changed. If the taste isn't affected to a great extent, they get changed. But there are still old cauldrons used for making desserts. They add something specia (GM, Revani Case)

One should stick to two things, pursuing innovations on the one hand, and being cautious on the other hand. We should be innovative in all areas, but we should implement these innovations very carefully (GM, Bake Case) 
Figure 1

Final Data Structure

First-order categories

Second-order themes

Aggregate dimensions

Second-order themes

First-order categories

- Memorializing the

values of iconic

founders

- Holding on to the

culture of family

craftsmanship

- Sustaining family

values and beliefs

\section{- Regretting the loss of} tradition

- Searching in the past

to trace tradition

- Recovering tradition
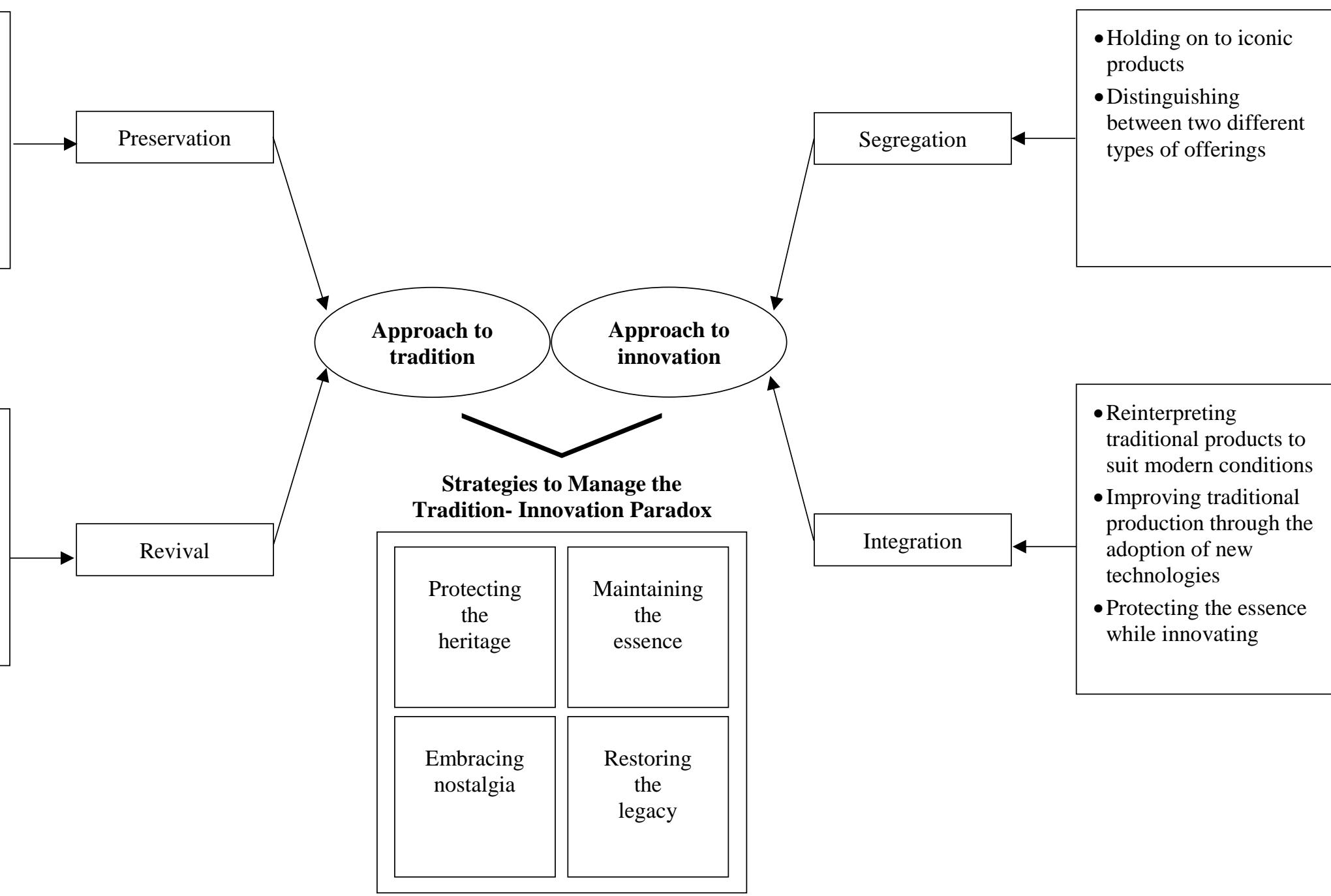
Figure 2

Types of Strategies to Manage the Tradition and Innovation Paradox in Family Firms

\section{Approach to innovation}

\begin{tabular}{|c|c|c|}
\hline & Segregation & Integration \\
\hline D & $\begin{array}{c}\text { Strategy 1: } \\
\text { Protecting } \\
\text { the } \\
\text { heritage } \\
\text { Quartz Case, } \\
\text { Winery Case }\end{array}$ & $\begin{array}{c}\text { Strategy 2: } \\
\text { Maintaining } \\
\text { the } \\
\text { essence } \\
\text { Revani Case, } \\
\text { Bake Case }\end{array}$ \\
\hline $\begin{array}{l}\overline{0} \\
\stackrel{0}{0} \\
\frac{2}{2} \\
\frac{2}{2}\end{array}$ & $\begin{array}{l}\text { Strategy 4: } \\
\text { Embracing } \\
\text { nostalgia } \\
\text { Gazoz Case, } \\
\text { Diary Case }\end{array}$ & $\begin{array}{c}\text { Strategy 3: } \\
\text { Restoring } \\
\text { the } \\
\text { legacy } \\
\text { Smetana Case, } \\
\text { Baklava Case }\end{array}$ \\
\hline
\end{tabular}

Figure 3

A Family Imprinting Perspective on Managing the Tradition and Innovation Paradox in Family Firms

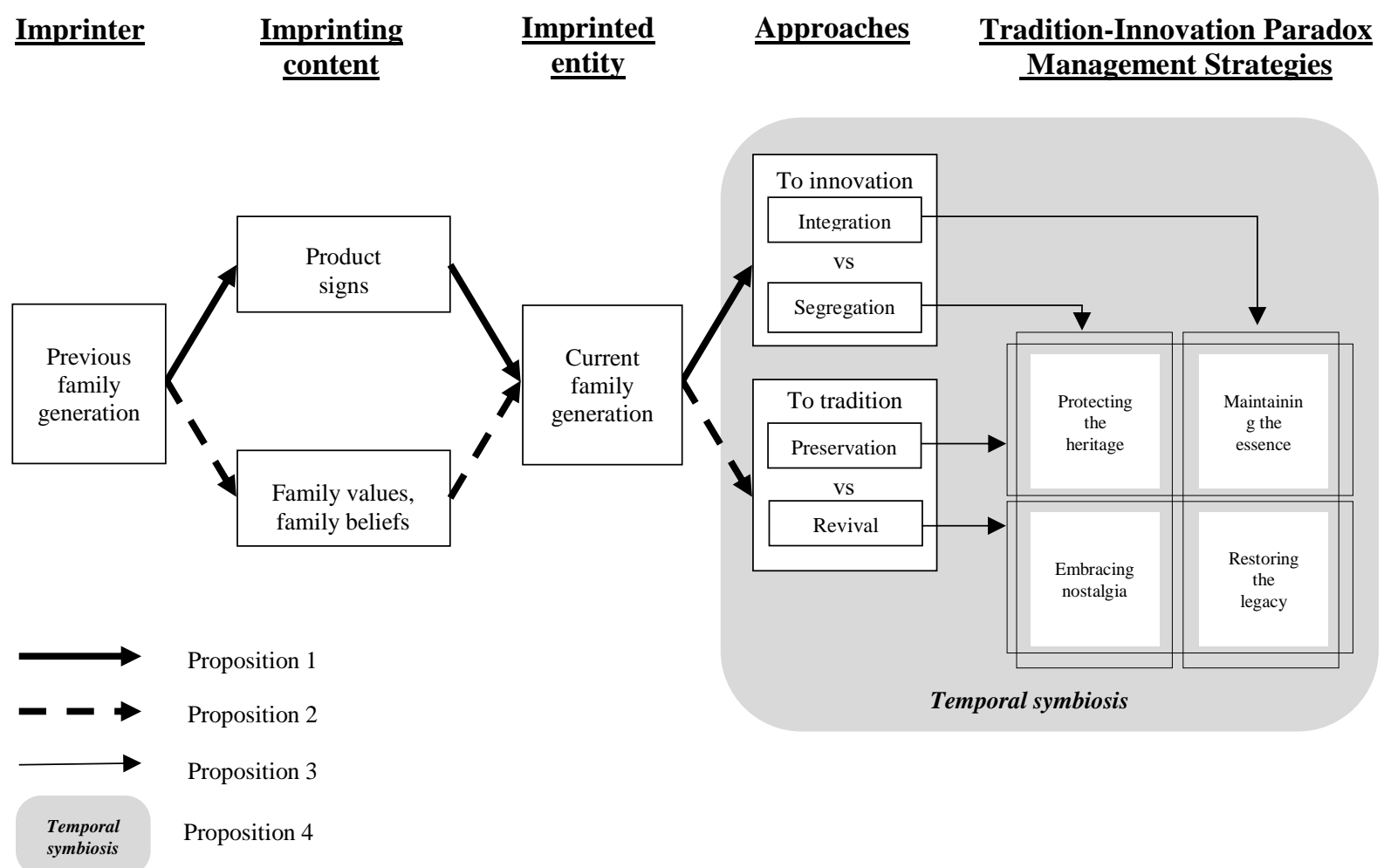

